(Pre-print final draft. The paper was published in: New Zealand Economic Papers, Volume 38(1), June 2004, pp. 87-99)

\title{
The Transaction Sector, the Information Economy, and Economic Growth in New Zealand: Taking Hazledine Seriously*
}

\author{
Hans-Jürgen Engelbrecht \\ Department of Applied and International Economics \\ Massey University \\ Palmerston North \\ NEW ZEALAND
}

\begin{abstract}
The aim of this paper is to broaden the discussion about the role of the 'transaction sector' in New Zealand economic growth by relating it to the seemingly alternative, but actually complementary, concept of the rise of the information economy, and by indicating some new directions for research. First, a brief overview of approaches to measuring transaction costs is provided. Secondly, the complementary nature of the information economy and transaction sector concepts is discussed. Next, empirical estimates of the information and transaction workforces are presented. Fourthly, the major points that need to be considered in the development of an extended, more complex, hypothesis about the role of the transaction sector in New Zealand economic growth are discussed, and a first version of such a hypothesis is put forward.
\end{abstract}

JEL classification: D23, J4, O1, P11

* I thank Tim Hazledine and a referee for useful comments. The second part of the title is a play on Hazledine (1998). It was also partly inspired by Scobie’s (1998) review in this journal. 


\section{Introduction}

In a number of publications Hazledine has reported estimates of the size and growth of New Zealand's ‘transaction sector' (Hazledine, 1998, 2001a,b). His analysis is mainly based on observed changes in the occupational composition of the labour force from the mid-1950s to the late 1990s. Interpreting his findings, Hazledine suggests something like the following hypothesis about NZ's recent economic growth (or rather the lack of it):

Pre-1984 NZ was rich in social capital and had a very small transaction sector. The economic restructuring from 1984 onwards destroyed social capital, necessitating a large increase in the (absolute and relative) size of the transaction sector, which, in particular, led to a disproportionate rise in the size of management and a 'shock collapse in managerial productivity'. This, in turn, was one of the main factors responsible for the subsequent low economic growth.

Hazledine's hypothesis remains to be tested formally. However, it has already begun to become part of NZ's folklore. For example, Belich (2001, p. 458) states that Hazledine's general picture of declining social capital and rising transactional costs is convincing, and that it does help to explain part of the disappointing growth performance of the NZ economy. ${ }^{1}$

The aim of this paper is to put Hazledine's transaction sector results into perspective by comparing them with empirical findings for NZ's information workforce, and by exploring elements of an extended, more complex, hypothesis, i.e. one that focuses on the nexus between economic growth, the information economy, the transaction sector, social and human capital. It is hoped that the debate started by Hazledine, and the more complex picture sketched below, will stimulate further research on so far neglected aspects of NZ's economic history and recent growth performance. This is important because, given the current state of knowledge, “...the mystery of New

\footnotetext{
${ }^{1}$ However, Belich argues that Hazledine blames too much on the economic reforms since 1984, e.g. he observes that the increase in the manager to worker ratio was greater during the pre-reform period.
} 
Zealand's disappointing growth performance remains unsolved” (Hazledine, 2003, p. 2).

Section 2 provides a brief overview of the different approaches to empirical research in transaction cost economics. Next, I comment on the concepts of the information economy and that of the transaction sector, and how they are related (Section 3). It will be argued that differences between them are more apparent than real, especially with regard to empirical implementation at the aggregate level and when it comes to analysing changes in the 'organisational technology' of the economy, i.e. when analysing (private and public) bureaucracies or the 'management sector'. Section 4 discusses estimates of NZ's information and transaction workforces. Elements of an extended, more complex, hypothesis about the role of the transaction sector in recent and future NZ economic growth is put forward in Section 5. Section 6 contains concluding comments.

\section{Empirical Transaction Cost Economics Research}

Empirical research in transaction cost economics has progressed in different ways, reflecting the fact that there is as yet no unified theoretical definition of transaction costs, or agreement on how to measure them. Recently, Wang $(2003)^{2}$ has provided a useful taxonomy of the different approaches.

1. There is a long tradition of measuring transaction costs in financial economics, where they are generally understood to be the costs of investing in financial markets, e.g. brokerage fees.

2. Williamsonian transaction cost economics focuses on the relative ranking of transaction costs associated with alternative forms of economic organisation and contractual arrangement, eschewing the direct measurement of transaction

\footnotetext{
${ }^{2}$ Wang's paper is available from the website of the Ronald Coase Institute (http://coase.org/). The Institute's mission is to promote research by and networking of scholars in the areas of institutional and transaction cost economics. Its current research focuses explicitly on the measurement of transaction costs.
} 
costs in absolute terms. ${ }^{3}$ This research program constitutes the majority of empirical studies in the New Institutional Economics. Growth of this literature has been exponential since the 1980s (Williamson, 2000).

3. Transaction sector measurement: This approach is due to Wallis and North's (1986) attempt to explicitly measure transaction costs at the economy-wide level for the U.S. Their approach has been applied with variations to a number of other economies, e.g. Australia (Dollery and Leong, 1998) and New Zealand (Hazledine, 1998, 2001a,b). However, this line of research is not yet well developed. There are numerous outstanding measurement issues, and the relationship between the aggregate measures of transaction costs and the evidence at the micro level is as yet unresolved (Wang, 2003, p. 5).

4. Wallis and North (1986, p. 99) admit that their conception of the transaction sector only accounts for transaction costs that are 'occasioned by market activity', i.e. they only measure transaction services, not total transaction costs. Although that includes the resources used up by private and public bureaucracies, it does not include resources spent in waiting, getting permits to do business, cutting through red tape, bribing officials etc. Such costs are not normally measured or even observable, despite being larger than the 'transaction sector' in some countries. The seminal work of De Soto (1989) has filled this gap, providing estimates of the costs of setting up business and giving rise to further studies of these "informal transaction costs". ${ }^{4}$ To a lesser degree these costs are also important in OECD countries. ${ }^{5}$

5. Transaction cost economics also plays an important part in the environmental and ecological economics literature on emission trading, and in the literature

\footnotetext{
${ }^{3}$ Statistical relationships between proxy variables for transaction costs (e.g. uncertainty, asset specificity, transaction frequency, and organisational governance) are usually tested.

${ }^{4}$ Wang (2003) uses the term 'non-market(ed) transaction costs' instead. However, I regard this term as confusing, given the fact that resources spent on private and public bureaucracies (i.e. the 'in-house' or 'intra-firm' transaction sector) are included in Wallis and North's transaction sector measure. The term 'informal' makes it clear that these costs are incurred outside formal organisations. The term also has natural affinity with the concept of the 'informal sector' in developing countries. ${ }^{5}$ A recent report by the OECD (2003, especially chapter 4) provides evidence that burdensome regulations on entrepreneurial activity as well as high costs of adjusting the workforce negatively affect the entry of new small firms.
} 
on the use of incentive mechanisms in environmental protection in general (e.g. policy-induced transaction costs).

6. Proxy measures of transaction costs have been included in the large empirical (mainly macro-economic) literature on economic growth and institutions. ${ }^{6}$

This is currently a lively topic in growth research.

7. Economic sociology and psychology are main contributors to the 'economics of identity’ (Akerlof and Kranton, 2000), which leads to agent-specific transaction costs where identity matters (most of the approaches to transaction costs focus on transaction-specific costs instead). Different individuals may face very different transaction costs when trying to conduct the same business, e.g. due to discrimination, network membership requiring idiosyncratic qualities, and other non-economic institutions, and they have different levels of capacity to cope with them.

In the following my concern is solely with transaction sector measurement. There is evidence that less than careful use of the transaction sector concept has led to misleading conclusions. For example, some authors have subtracted all 'transaction industries’ from U.S. GNP, re-calculated aggregate productivity growth, and concluded that such industries have thwarted US productivity growth. ${ }^{7}$ Such a simplistic approach is inappropriate, as was pointed out by Wallis and North (1988), because most transaction sector services are intermediate, not final, services. The relationship between transaction sector growth and economic growth is less straightforward than it might seem at first glance.

\section{Information Economy versus Transaction Sector?}

Most economists would agree that the creation, distribution, adoption and exploitation of knowledge has become much more central to wealth creation than it used to be, though it has always been important. This view is reflected in many studies on aspects of the information- and knowledge-based economy published by the OECD in recent decades. An information and knowledge perspective has also been accepted by many

\footnotetext{
${ }^{6}$ Some of the major studies are Knack and Keefer (1997) and Hall and Jones (1999).

${ }^{7}$ See, e.g., Fuess, Jr. and van den Berg (1992).
} 
non-mainstream economists (see, for example, Hodgson, 1999, Metcalfe, 2001) and has led to a growing literature on 'knowledge management' in management science.

Hazledine (2001b) mentions the possibility that alternative partitions of the occupation data, for example in terms of the 'information sector', may turn out to be more pertinent than his transaction sector measure. He specifically refers to a paper of mine that provides a detailed comparison of Wallis and North's (1986) transaction sector concept and Porat and Rubin’s (1977) information economy concept (Engelbrecht, 1997a). As explained in my paper, although there are some theoretical and conceptual differences, the two approaches are very similar: In both cases, some industries are completely designated transaction or information industries, while for the rest of the economy, only the in-house transaction/information sector (i.e. the management sector) is counted. However, Wallis and North's measurement of the organisational technology of an economy is somewhat simpler in the sense that only labour inputs into the bureaucracies are taken into account, whereas Porat and Rubin also account for capital consumption etc.

\section{The New Zealand Information and Transaction Sector Workforces}

To the best of my knowledge, Porat and Rubin's concept of the information economy has not yet been fully operationalised for NZ. My own studies of NZ's information workforce are only a first step in implementing their approach, but the results invite comparison with Hazledine's transaction workforce estimates. Both Hazledine and I focus on employment by occupation data as measures for the resources used in information or transaction activities in the economy.

NZ's information workforce was first measured by Conway (1981). In a number of publications I have updated measurement to 2001 and also analysed the composition of information employment by skill category, gender, and ethnicity. The definition of information workers used is broadly that of the OECD (1981, pp. 22-3), i.e. all people working in occupations whose primary purpose is to produce, process or distribute information, or provide infrastructure support for these activities. As discussed elsewhere (Engelbrecht, 2000), measurement of the information workforce is not a 
straightforward task, involving subjective choices and compromises dictated by the available occupation data.

The definition of transaction workers is discussed at length in Wallis and North (1986) and Hazledine (2001a,b). Hazledine (2001b) includes all managers, clerks, and half of all sales workers. Wallis and North (1986, p. 126-7) also include some professional workers (e. g. accountants, lawyers, judges) and protective workers (e.g. police, guards). Hazledine (2001b) makes a distinction between people employed in transaction occupations and total 'transaction employment'. The latter also includes non-transaction workers in the transaction industries. Moreover, in contrast to Wallis and North, Hazledine includes the unemployed in the transaction sector.

A comparison of the relative sizes of NZ's information and transaction sector workforces at the aggregate level is presented in Table 1. Note that, for a number of reasons, they are not fully comparable. I include only full-time information workers, whereas Hazledine reports his estimates in terms of full-time equivalent, which includes part-time workers. ${ }^{8}$ Also, the information workforce percentages are not fully comparable over time because my own definition of the information workforce is somewhat narrower than Conway's (i.e. see my somewhat smaller percentage for 1976).

All three series of estimates shown in Table 1 have increased substantially from 1956 to 1996, with transaction workers and transaction employment showing a slight decline since then. Considering the differences in the percentages of information and transaction workers, it would seem that while the relative size of private and public bureaucracies has been stagnating during the 1990s, there has been continued growth of 'professional \& technical' (non-managerial) workers who are counted as part of the information workforce but not the transaction workforce. This warrants closer

\footnotetext{
${ }^{8}$ Engelbrecht $(2000,2001)$ reports separate estimates for part-time information employment for the years 1976, 1981 and 1996. The percentages of part-time information workers in the total part-time workforce are smaller than those for fulltime workers, and they seem to have changed little over time (i.e. 32.9\% in 1986 and $32.2 \%$ in 1996). As a result, the percentages of full-time equivalent information workers in NZ are somewhat lower than those shown in Table 1. For example, the 1996 percentage would be $44.0 \%$, i.e. reduced from $45.7 \%$, but still substantially higher than the estimate for the transaction worker percentage.
} 
examination in future research. Note that the information workforce includes most of the high-skilled professional jobs that rank highest in terms of the NZ socio-economic index (and mostly higher even than 'corporate managers'-- see Davis et al., 2003). ${ }^{9}$

\begin{tabular}{|c|c|c|c|}
\hline Table 1: & \multicolumn{3}{|c|}{$\begin{array}{l}\text { The relative size of New Zealand's information and } \\
\text { transactions workforces }\end{array}$} \\
\hline Year & $\begin{array}{c}\text { (a) Percentage } \\
\text { of information } \\
\text { workers }\end{array}$ & $\begin{array}{c}\text { (b) Percentage } \\
\text { of transaction } \\
\text { workers }\end{array}$ & $\begin{array}{l}\text { (c) Percentage } \\
\text { of transaction } \\
\text { employment }\end{array}$ \\
\hline 1956 & 25.7 & 21.0 & 25.7 \\
\hline 1961 & 28.9 & 22.9 & 27.6 \\
\hline 1966 & 30.3 & 24.1 & 28.9 \\
\hline 1971 & 33.7 & 24.9 & 30.2 \\
\hline 1976 & $35.9 / 34.6$ & 25.4 & 31.4 \\
\hline 1981 & 35.0 & 25.9 & 33.4 \\
\hline 1986 & 38.3 & 28.5 & 37.0 \\
\hline 1991 & 44.6 & 29.8 & 40.3 \\
\hline 1996 & 45.7 & 30.4 & 40.6 \\
\hline 1998 & - & 29.7 & 39.8 \\
\hline 2001 & 47.5 & - & - \\
\hline \multicolumn{4}{|c|}{$\begin{array}{l}\text { Data sources: (a) information workers: } 1956 \text { to 1976, in italics (Conway, } \\
\text { 1981), } 1976 \text { to } 1996 \text { (Engelbrecht, 2001), } 2001 \text { (Engelbrecht and Mahon, } \\
\text { 2003); (b) transaction workers (excluding the unemployed): Hazledine } \\
\text { (2001b, Table 1, rows } 4 \text { and 13); (c) transaction employment (excluding } \\
\text { the unemployed): Hazledine (2001b, Table 1, rows } 12 \text { and 13). }\end{array}$} \\
\hline
\end{tabular}

I briefly highlight some of the features of information employment over time. Firstly, during 1976-1996, which was of course a period of radical economic and social change, NZ experienced a large increase in the relative size of its information workforce, and a shift towards higher skilled information occupations (with more than 50 percent of the information workforce employed in high-skilled information occupations by 1996). After lagging behind the US for a long time, by 1996 the relative size of NZ's information workforce seemed similar to that of the US (Engelbrecht, 2000).

\footnotetext{
${ }^{9}$ For a detailed list of NZ information occupations at the four-digit level, see Engelbrecht (2001).
} 
Secondly, by 1996 about 55 percent of the full-time female workforce was employed in information occupations, compared to about 40 percent of the male workforce (the percentages for part-time information employment are much lower for both gender, i.e. about 22 percent for males and about 36 percent for females in 1996). However, in 1996 high-skilled workers made up a relatively larger proportion of the male (about 62 percent), compared to the female (about 41 percent), information workforce (Engelbrecht, 2001).

Thirdly, Maori are statistically underrepresented in the information workforce. In 2001, about 35 percent of the Maori workforce was employed in information occupations compared to about 49 percent of the non-Maori workforce. There is also an important gender dimension: Maori women are significantly more likely to participate in the information workforce than Maori men (in 2001, only about 25 percent of the male Maori workforce was employed in information occupations, compared to about 49 percent of the female Maori workforce) (Engelbrecht and Mahon, 2003).

The size and growth of the management occupation group in the workforce may call for an analysis that allows for the possibility of organisational inefficiency at the economy-wide and industry level, not just at the firm-level. This possibility has been explored in the non-mainstream literature for a long time (see Alexander, 1992, and the references cited therein). In some of my earlier research I found that a relatively large management sector, interpreted as relative organisational inefficiency, had a negative impact on comparative advantage in manufacturing in countries as diverse as Japan, Australia and the U.S. ${ }^{10}$ Moreover, it was the narrower definition of managers and clerical workers divided by blue collar workers instead of wider definitions of information divided by non-information workers or white collar (non-production) divided by blue-collar (production) workers, that produced the larger negative impact! More recently Feldstein (2001, p. 392) has argued that productivity gains in the U.S. will primarily come from advances in information technology that will reduce the

\footnotetext{
${ }^{10}$ See Engelbrecht (1991, 1994, 1997b). In these studies a proxy for the relative size of the management sector is entered alongside conventional determinants of comparative advantage. The findings support the view that organisational factors are at least as important as conventional trade determinants, if not more so.
} 
number of non-production workers in middle management jobs per unit of output. In short, there is recognition from diverse quarters that the size of the management sector matters for macro-economic performance.

\section{Towards an Extended Hypothesis with Social Capital}

The relationship between transaction costs (and therefore the size of the transaction sector) and the concept of 'social capital' needs to be analysed in much more detail. Below I briefly introduce some of the major points that could be considered in the development of an extended, more complex, hypothesis.

Firstly, as in the case of transaction costs, there is as yet no broadly accepted definition of 'social capital' (or even agreement that the term should be used at all). The range of definitions in the literature includes: the amount of trust and cooperation across the economy; the extent of community and social networks; and even a person's social skills. Even when a common definition is used, there may not be agreement about measurement. ${ }^{11}$

Secondly, Hazledine seems to presume that the more social capital there is, the better off an economy and society will be. However, such a one-dimensional view of the role of social capital in economic development does not take account of its complexity and dynamic character, and its interactions with other forms of capital. It is recognised in the literature that some social capital can benefit certain groups, at the expense of other groups or even of society at large. ${ }^{12}$ Alternatively, Hazledine might be aware that social capital can be negative for certain groups, but because his findings pertain to the macro level of analysis, he focuses on the net effects only. This

\footnotetext{
${ }^{11}$ See, e.g., Paldam, 2000, and Durlauf, 2002. For a recent review of social capital theories and concepts, as well as related empirical work, see Productivity Commission (2003).

${ }^{12}$ See, e.g., Grootaert and van Bastelaer (2002) in the introduction to their book that summarizes much of the World Bank's 'social capital initiative' of the 1990s, and Westlund and Bolton (2003).
} 
highlights the need to disaggregate the analysis, and to address issues arising in the aggregation from micro to macro level. ${ }^{13}$

Thirdly, the literature on social capital in developing countries tells us that during periods of major economic reforms and structural change, social capital is usually destroyed, and that these losses of social capital are, partly or wholly, compensated by increases in physical and human capital. This results in smaller productivity increases than those that might otherwise have been expected (Hoff and Stiglitz, 2001, p. 399). The often observed strong positive correlation between social and human capital (Glaeser et al., 2002, p. F455) then suggests that when new human capital is being developed, new social capital is also likely to be created. This argument is also supported by Helliwell and Putnam’s (1999) findings for the U.S. Moreover, in a careful cross-country study, Denny (2003) finds a consistently positive effect of an additional year of education on participation in voluntary and community activities and organisations ('volunteering') of around 2 or 3\% for most countries, with estimates for English speaking countries, including NZ, being at the higher end. He is unable to reject the hypothesis that education is an exogenous variable. Acquiring a four year university degree is associated with an approximately $10 \%$ higher probability of volunteering. ${ }^{14}$

Others have argued that there may be significant substitution effects between some forms of human and social capital (Piazza-Georgi, 2002), and that causation can go from social capital to human capital (Coleman, 1988), as well as either inhibiting or facilitating entrepreneurship (Westlund and Bolton, 2003).

Fourthly, there may be an important international dimension to the relationship between transaction costs and social capital. Belich (2001) has argued that until

\footnotetext{
${ }^{13}$ Below the aggregate level of analysis, a diverse picture is beginning to emerge. For example, Möllering (2002) tests six representative theoretical positions regarding the impact of trustworthiness on the organisation of inter-firm relations. His empirical findings lead him to dismiss the 'widely accepted' argument that trust reduces the need for and cost of hierarchy and control. He argues that economic theory has to become more complex and more pluralistic if 'trust' is to be fruitfully incorporated. ${ }^{14}$ However, whether all university degrees are more or less equal in terms of creating social capital is an intriguing question, especially for economists (see Frank et al., 1996).
} 
Britain joined the European Economic Community in 1973, NZ had low international transaction costs because it shared 'transnational social capital' with that country, i.e. NZ had what one might call savings due to culturally familiar international trading networks. Since then, NZ's trade has greatly diversified, requiring higher transaction costs because of lower, or at first non-existent, levels of shared social capital. Belich's hypothesis complements Hazledine's more domestically focussed hypothesis. It, too, remains to be tested formally.

In summary, the question of the relationships between human capital, social capital, transaction costs and productivity and output growth, requires further theoretical and empirical research attention. ${ }^{15}$ Recently, McCann (2003) adopted a transaction cost perspective in order to analyse NZ's future trade patterns and growth performance. He notes that NZ has a highly educated labour force and low population levels. This, potentially, provides for a much higher level of inter-personal connectedness, i.e. a form of social capital, than is possible in high population societies (ibid, p. 22). He seems to imply that NZ has a potential advantage in the development of certain types of social capital that are necessary for future economic growth, and that public policy also has a role to play in this. ${ }^{16}$

An extended hypothesis about the role of the transaction sector and social capital in NZ economic growth should take the above elements into account, e.g. the heterogeneity of social capital, the fact that it can have negative impacts on growth, that human capital accumulation may result in social capital accumulation, and the international dimension. A general, albeit simple, version of such a hypothesis might be stated as follows: The destruction of certain forms of social capital and the rise in the percentage of transaction workers was a necessary part of the economic reforms in NZ. The social capital invested in the old NZ in lobbying government, or in rent-

\footnotetext{
${ }^{15}$ For example, Bils and Klenow (2000) find that the impact of human capital on growth is much weaker than that of growth on human capital, though they cannot exclude the possibility of omitted factors causing the correlation between the two variables.

${ }^{16}$ See Productivity Commission (2003, section 4) for a general discussion of social capital and public policy analysis. However, it seems fair to say that the question what role public policy should play in creating social capital is as yet unsettled, e.g. the case for massive investment in social capital (in contrast to the case for human capital) has not yet been made (Grootaert and Bastelaer, 2002, Piazza-Greorgi, 2002).
} 
seeking activities in general, had to be 'depreciated'. The increased public and private investment in education in recent years, particularly in terms of the number of people enrolled in tertiary education, is resulting in new forms of national and trans-national social capital, the formation of which might be supported and sped up by specific public policies. None of this necessarily contradicts Hazledine's hypothesis. Rather, it goes beyond a somewhat static view of the role and impact of transaction costs towards a more dynamic and differentiated analysis of the changing relationships.

\section{Concluding Comments}

This paper has argued that Hazledine's hypothesis about the growth and impact of NZ's transaction sector should not be dismissed, but that it can only be regarded as a first working hypothesis on the topic. Reality is less straightforward and potentially much more interesting. Moreover, it would be wrong to regard analysis of the information workforce as an unrelated and competing alternative form of analysis; rather, it is complementary to that of the transaction sector workforce.

There can be high- or low-productivity information- and knowledge-based economies. Growth of the transaction sector, especially in terms of the relative size of the management sector, may well be part of the explanation of low productivity growth in NZ. However, measuring the information or transaction sector workforce is not the same as explaining its size and impacts. The characteristics of organisational technology and their impact on NZ economic growth have not yet been rigorously analysed and empirically tested. Any such attempt should concentrate on the dynamic links between transaction costs, human capital and social capital. 


\section{References:}

Akerlof, G. and R. Kranton (2000), “Economics of Identity”, Quarterly Journal of Economics, 115(3), 715-753.

Alexander, D. (1992), “Resource Use and U.S. Manufacturing Productivity Growth”, Journal of Post Keynesian Economics, 14(3), 389-407.

Belich, J. (2001), Paradise Reforged: A History of the New Zealanders From the 1880s to the Year 2000, Penguin Books: Albany, Auckland.

Bils, M. and P. Klenow (2000), “ Does Schooling Cause Growth?”, American Economic Review, 90(5), pp. 1160-1183.

Coleman, J. (1988), “Social Capital in the Creation of Human Capital”, American Journal of Sociology, Vol. 94, Supplement, S95-S120.

Conway, M. (1981), "Information Occupations: The New Dominant in the New Zealand Work Force”, in: Commission for the Future (eds.), Network New Zealand Working Papers, Paper No. 2, Wellington.

Davis, P., Jenkin, G. and P. Coope (2003), New Zealand Socio-Economic Index 1996: An Update and Revision of the New Zealand Socio-Economic Index of Occupational Status, Statistics New Zealand: Wellington.

De Soto, H. (1989), The Other Path, Harper \& Row: New York.

Denny, K. (2003), The Effects of Human Capital on Social Capital: A Cross-Country Analysis, Institute of Fiscal Studies, Working Paper 03/16, September. http://www.ifs.org.uk/workingpapers/wp0316.pdf (accessed 23/10/03)

Dollery, B. and W. H. Leong (1998), "Measuring the Transaction Sector in the Australian Economy, 1911-1991”, Australian Economic History Review, 38(3), 207-231. 
Durlauf, S. (2002), “Symposium on Social Capital: Introduction”, Economic Journal, 112, F417-F418.

Engelbrecht, H.-J. (1991), “Information Services, Private Bureaucracies, and Japan’s Comparative Advantage”, Review of Economics and Statistics, 73(4), 716-719.

Engelbrecht, H.-J. (1994), “Private Bureaucracies, Organizational Efficiency, and Australia’s Manufacturing Trade Structure: A Comparison with Japan”, International Review of Applied Economics, 8(3), 266-282.

Engelbrecht, H.-J. (1997a), “A Comparison and Critical Assessment of Porat and Rubin's Information Economy and Wallis and North's Transaction Sector”, Information Economics and Policy, 9(4), 271-290.

Engelbrecht, H.-J. (1997b), “Corporate Bureaucracies and United States Competitiveness”, International Journal of the Economics of Business, 4(2), 129-153.

Engelbrecht, H.-J. (2000), “Towards a Knowledge Economy? Changes in New Zealand’s Information Workforce 1976-1996”, Prometheus, 18(3), 265-282.

Engelbrecht, H.-J. (2001), “The Growth and Gender Composition of New Zealand's Information Work Force”, in: Philip S. Morrison (ed.), Labour, Employment and Work in New Zealand 2000: Proceedings of the Ninth Conference, November 23 and 24, 2000, Victoria University of Wellington, Wellington, 123-133.

Engelbrecht, H.-J. and A. Mahon (2003), Maori and the Information Workforce, 1991-2001, Discussion Paper No. 03.03, Department of Applied and International Economics, Massey University, Palmerston North, New Zealand.

Feldstein, M. (2001), “Overview”, in "Economic Policy for the Information Economy”, Symposium sponsored by the Federal Reserve Bank of Kansas 
City, Jackson Hole, Wyoming, August 30 - September 1, pp. 391-397. http://www.kc.frb.org/PUBLICAT/SYMPOS/2001/sym01prg.htm (accessed 23/10/03)

Frank, R., Gilovich, T. and D. Regan (1996), “Do Economists Make Bad Citizens?”, Journal of Economic Perspectives, 10(1), 187-192.

Fuess, Jr., S. and H. van den Berg (1992), “The Impact of Transaction Activities on U.S. Productivity Growth”, Economics Letters, 38(2), 243-247.

Glaeser, E., Laibson, D. and B. Sacerdote (2002), “An Economic Approach to Social Capital”, Economic Journal, 112, F437-F458.

Grootaert, C. and T. van Bastelaer (eds.)(2002), The Role of Social Capital in Development: An Empirical Assessment, Cambridge University Press: Cambridge, U.K.

Hall, R. and C. Jones (1999), "Why Do Some Countries Produce So Much More Output Per Worker Than Others?”, Quarterly Journal of Economics, 114(1), 83-116.

Hazledine, T. (1998), Taking New Zealand Seriously: The Economics of Decency, Harper Collins: Auckland.

Hazledine, T. (2001a), “Transaction Efficiency in New Zealand and Australia, 196196”, chapter 14 in: Harry Bloch and Peter Kenyon (eds.), Creating an Internationally Competitive Economy, Palgrave: Houndmills, Basingstoke and New York, 250-270.

Hazledine, T. (2001b), “Measuring the New Zealand Transaction Sector, 1956-98, with an Australian Comparison”, New Zealand Economic Papers, 35(1), 77100. 
Hazledine, T. (2003), “Editor’s Introduction to the Symposium on New Zealand Growth and Productivity”, New Zealand Economic Papers, 37(1), 1-3.

Helliwell, J. and R. Putnam (1999), Education and Social Capital, National Bureau of Economic Research Working Paper No. 7121.

Hodgson, G. (1999), Economics \& Utopia: Why the Learning Economy is Not the End of History, Routledge: London and New York.

Hoff, K. and J. Stiglitz (2001), “Modern Economic Theory and Development”, in Gerald Meier and Joseph Stiglitz (eds.), Frontiers of Development Economics: The Future in Perspective, The World Bank and Oxford University Press, 389-459.

Knack, S. and P. Keefer (1997), “Does Social Capital Have an Economic Payoff? A Cross-Country Investigation”, Quarterly Journal of Economics, 112(4), 12511288.

McCann, P. (2003), Geography, Trade and Growth: Problems and Possibilities for the New Zealand Economy, New Zealand Treasury, Working Paper 03/03, June. http://www.treasury.govt.nz/workingpapers/2003/03-03.asp (accessed 23/10/03)

Metcalfe, J. S. (2001), “Institutions and Progress”, Industrial and Corporate Change, 10(3), 561-586.

Möllering, G. (2002), “Perceived Trustworthiness and Inter-Firm Governance: Empirical Findings From the UK Printing Industry”, Cambridge Journal of Economics, 26(2), 139-160.

OECD (1981), Information Activities, Electronics and Telecommunications Technologies: Impact on Employment, Growth and Trade, Volume 1, Paris.

OECD (2003), The Sources of Economic Growth in OECD Countries, Paris. 
Paldam, M. (2000), “Social Capital: One or Many? Definition and Measurement”, Journal of Economic Surveys, 14(5), 629-653.

Piazza-Georgi, B. (2002), “The Role of Human and Social Capital in Growth: Extending Our Understanding”, Cambridge Journal of Economics, 26(4), 461479.

Porat, M. and M. Rubin (1977), The Information Economy (in nine volumes), Washington D.C.: US Department of Commerce, Office of Telecommunications, Special Publication 77-12.

Productivity Commission (2003), Social Capital: Reviewing the Concept and its Policy Implications, Research Paper, Ausinfo, Canberra, July. http://www.pc.gov.au/research/commres/socialcapital/index.html (accessed 23/10/03)

Scobie, G. (1998), Review of: Taking New Zealand Seriously, by Tim Hazledine, New Zealand Economic Papers, 32(2), 225-229.

Wallis, J. and D. North (1986), "Measuring the Transaction Sector in the American Economy, 1870-1970”, chapter 3 in: Stanley L. Engerman and Robert Z. Gallman (eds.), Long-Term Factors in American Economic Growth, Volume 51, NBER Studies in Income and Wealth, University of Chicago Press, 95148.

Wallis, J. and D. North (1988), "Should Transaction Costs be Subtracted from Gross National Product?”, Journal of Economic History, 48(3), 651-654.

Wang, N. (2003), Measuring Transaction Costs: An Incomplete Survey, Paper presented to the Conference on Transaction Costs, Ronald Coase Institute, Chicago, Illinois, February 21-23. 
Westlund, H. and R. Bolton (2003), “Local Social Capital and Entrepreneurship”, Small Business Economics, 21, 77-113.

Williamson, O. (2000), “The New Institutional Economics: Taking Stock, Looking Ahead”, Journal of Economic Literature, 38(3), 595-613. 
